\title{
BERITAKAN INJIL KEPADA SEGALA MAKHLUK (Sebuah Uraian Ekologi-Teologis)
}

\author{
Ibelala Gea \\ Institut Agama Kristen Negeri Tarutung \\ Email:_.martianus@yahoo.com
}

\begin{abstract}
Abstrak-Artikel ini bertujuan mendeskripsikan hasil penelitian tentang bagaimana memberitakan Injil kepada seluruh makhluk, bertolak dari Markus 16:15-16. Dunia adalah sebagai alamat pemberitaan Injil, bukan hanya kepada manusia melainkan kepada segala makhluk. Penulis Injil Markus hendak menjelaskan bahwa dunia identik dengan kejahatan, sebab itu Injil berfungsi menggarami dunia yang penuh kejahatan itu, karena itu ketika Iniil diberitakan kepada orang-orang jahat, diharapkan akan mengubah mindset dan perilaku manusia. Perilaku manusia yang serakah dan tamak yang hanya memandang alam sebagai komoditi. Pemberitaan Injil adalah menyadarkan manusia agar tidak hanya memandang alam sebagai kekuasaan (dominio) tetapi sebagai sesama ciptaan, sahabat yang bersifat communio.
\end{abstract}

Kata Kunci: Injil dan Segala makhluk

\section{PENDAHULUAN}

Memberitakan Injil adalah sebagai tugas orang Kristen. Setiap pribadi yang sudah diselamatkan oleh Yesus Kristus, memiliki tugas mutlak memberitakan Injil, baik secara internal maupun eksternal. Rasul Paulus yang sebelum bertobat disebut Saulus; setelah pertobatannya ketika dibutakan mata jasmaninya, namun hatinya dibuka oleh Tuhan. Paulus dalam suratnya kepada jemaat Korintus menyatakan bahwa:"Karena jika aku memberitakan Injil, aku tidak memiliki alasan untuk memegahkan diri sebab itu adalah keharusan bagiku. Celakalah aku jika aku tidak memberitakan Injil”. Pernyataan Rasul Paulus ini dalam bahasa Inggris dikatakan: "For it I preach the Gospel, I have nothing to boast of, for necessity is laid upon me, yes, doe is me if I do not preach the Gospel" (1 Korintus 9:16). Dari penekanan pernyataan Paulus mengungkapkan bahwa memberitakan Injil adalah keharusan dan kewajiban.

$$
\text { Dari Injil Matius 28:19-20 }
$$

dikatakan bahwa Tuhan Yesus telah memberi amanat atau perintah kepada para pengikut-Nya untuk memberitakan Injil. Dari amanat agung Yesus tersebut ada 3 (tiga) perintah penting yakni: memberitakan Injil, membaptis dan mengajar. Jika dilihat dari struktur amanat agung, maka yang menjadi point pertama adalah memberitakan Injil yang bertujuan untuk menjadikan semua bangsa menjadi murid atau pengikut Yesus. Kedua adalah membaptis dan ketiga mengajar.

$\begin{array}{cclr} & \text { Kekeliruan } & \text { para pemberita Injil } \\ \text { ketika } & \text { Injil } & \text { diberitakan sering }\end{array}$ mengesampingkan begitu saja tradisi setempat, sehingga seolah-olah Injil merupakan barang baru yang tidak bersangkutpaut dengan budaya. Demikian juga ketika alamat pemberitaan Injil yakni inti keselamatan itu hanya diperuntukkan kepada salah satu makhluk yakni manusia, juga hal ini merupakan diskriminasi terhadap makhluk-makhluk lain. Karena itu penulis Injil Markus 16:15-16 justru memproklamasikan bahwa objek pemberitaan Injil bukan hanya kepada manusia semata, melainkan kepada seluruh 
makhluk. Dari hal itu dapat difahami pola pikir penulis Injil Markus yang sadar benar bahwa segala makhluk adalah milik Allah, dan segala milik Allah adalah sebagai objek dan alamat keselamatan. Injil Markus memandang segala makhluk secara universal dalam kesatuan dan keutuhan ciptaan sebagai alamat penyelamatan Allah. Masalah yang krusial dalam kajian ini adalah jika memberitakan Injil kepada manusia adalah hal biasa, disampaikan dalam bentuk verbal dengan pendekatan dialog, percakapan, baik kepada perorangan dan kelompok. Pendekatan serta cara seperti itu telah diselenggarakan oleh para pemberita-pemberita Injil baik oleh para Rasul, gereja mula-mula dan para pemberita Injil atau Misionaris sebagaimana dikisahkan dalam sejarah gereja. Pemberitaan Injil seperti ini sungguh banyak tantangan terutama penolakan dari dunia ini. Penolakan itu tidak hanya verbal, juga sampai pada kematian fisik, sebab itu mereka sering disebut mati syahid atau martir. Akan tetapi dari pemberitaan Injil ala tulisan Markus kepada segala makhluk, hal itu berbicara bahwa pemberitaan Injil kepada manusia dapat dilakukan dengan verbal atau melalui panca indera, lalu bagaimana dengan pemberitaan Injil kepada makhluk diluar manusia, seperti kepada hewan di darat, di udara, di laut, tumbuh-tumbuhan didarat, ikan-ikan di lautan dan sebagainya.

Sejak zaman industrialisasi di Inggris, Eropa, baik di negara maju maupun di negara-negara berkembang menghadapi permasalahan polusi, limbah, pemanasan bumi secara global, sebab itu kerusakan lingkungan hidup adalah menjadi objek pemberitaan Injil. Berita Injil sangat dibutuhkan untuk menyadarkan masyarakat memahami kepadatan penduduk yang berdampak pada kerusakan lingkungan hidup. Sebab makin padatnya penduduk makin menyulitkan penataan lingkungan hidup (Herlianto, 1998 : 32).

Pemberitaan Injil kepada segala makhluk selain dibutuhkan kesediaan, kesadaran, kerelaan dari manusia untuk memberi perhatian merawat dan memelihara segala makhluk tersebut, juga manusia harus sadar bahwa makhluk diluar dirinya bukan hanya sebagai objek komoditi tetapi juga sebagai subjek dan sebagai sesama ciptaan.

Penelitian pada penulisan artikel ini, bertujuan untuk menjelaskan bagaimana memberitakan Injil kepada seluruh makhluk secara holistik, bertolak dari Markus 16:15-16. Memberitakan Injil kepada seluruh makhluk adalah bertujuan memberitakan kabar baik kepada seluruh ciptaan sebagai milik Tuhan. Manusia bukan sebagai makhluk tunggal di bumi ini, melainkan dia sebagai perpanjangan tangan Tuhan untuk melaksanakan pemeliharaan, perawatan kepada seluruh makhluk. Sebab itu seluruh makhluk dan alam bukan hanya dipahami sebagai kebutuhan komoditi melainkan sebagai sesama ciptaan dan sebagai sahabat yang saling memberi dan menerima, yang sama-sama sebagai alamat keselamatan yang telah dilaksanakan Allah dalam Yesus Kristus yang mengasihi seluruh dunia (Yohanes 3:16).

\section{METODE PENELITIAN}

Metode penelitian pada penulisan artikel ini adalah menggunakan metode kajian kualitatif dengan pendekatan Library Research; membaca dan membandingkan sejumlah referensi yang berhubungan dengan pemberitaan Injil secara ekologi dan teologis.

\section{PEMAHAMAN INJIL}

MENGENAI 
Pemahaman mengenai Injil, antara lain:

1. Menurut Kamus Alkitab, menuliskan bahwa Injil kata Yunani Evanggelion berarti kabar gembira, berita baik (LAI, 2011). Kedatangan Yesus Kristus, dan mulainya pemerintahan Allah di dunia ini merupakan inti Injil yang harus diberitakan ke mana-mana (Matius 24:24)

2. Menurut Ensiklopedi Alkitab Masa Kini (2005), Injil (Yunani:evanggelion, kabar baik). Dalam kesusateraan klasik, kata ini mengacu kepada pahala yang diberitakan untuk berita-berita baik (J.D. Douglas, : 346).

3. Menurut Ensiklopedi Alkitab Praktis (LLB, 1978), Injil berarti

a. Kabar baik dari Allah, yang mengutus Yesus Kristus untuk menjadi Tuhan dan Juruselamat manusia (1 Tesalonika 2:9), kata itu berasal dari kata bahasa Yunani yang secara harafiah berarti "kabar baik' (W.N. Mcelrath, Billy Mathias, 1978 : 56).

b. Salah satu diantara keempat buku utama mengenai riwayat hidup Yesus Kristus, Matius, Markus, Lukas dan Yohanes.

c. Sering juga dipakai untuk menyatakan seluruh Kitab Perjanjian Baru.

4. Menurut Rasul Paulus, dalam surat Roma 1:16-17, sebab aku mempunyai keyakinan yang kokoh dalam injil, karena Injil adalah kekuatan Allah yang menyelamatkan setiap orang percaya, pertama-tama orang Yahudi, tetapi juga orang Yunani, sebab di dalamnya nyata kebenaran Allah, yang bertolak dari iman dan memimpin kepada iman, seperti ada tertulis, orang benar akan hidup oleh iman.
Rasul Paulus menjelaskan ada dua arti Injil,yakni:

Pertama: secara garis besar Injil adalah kekuatan Allah artinya bahwa Injil berisi kabar baik yang menjelaskan bahwa kekuatan Illahi ada dalam Injil. Kekuatan Illahi tersebut telah mengubah dunia melalui kedatangan Yesus Kristus. Kekuatan itu dibuktikan dengan telah dikalahkan-Nya kuasa dosa dan dibenarkan-Nya manusia (Roma 4:25). Dengan telah mengalahkan dosa dan maut maka dianugerahkan-Nya kehidupan yang baru (Roma 7:1 4). Manusia berdosa telah memperoleh pengampunan dosa (Kolose 1:13) sehingga manusia sudah berdamai dengan Allah dan manusia hidup dalam damai sejahtera Allah (Roma 5:2)

Kedua: bahwa keselamatan tidak dibatasi, melainkan untuk semua orang mendapatkan anugerah Allah, baik orang Yahudi maupun orang Yunani. Keselamatan adalah lawan dari hukuman atau murka Allah (Roma 1:18) yang membawa kematian dan kebinasaan, akan tetapi dengan percaya kepada Kristus sebagai inti berita Injil, maka manusia diselamatkan dari murka Allah (Roma 5:9; 10:10)

Van den End, menuliskan bahwa Injil dapat juga disebutkan sebagai "Injil Allah", artinya bahwa Injil adalah kabar baik mengenai pembenaran manusia oleh iman dan sama-sama dianugerahkan keselamatan kepada orang Yahudi dan orang Yunani sehingga meniadakan tembok pemisah, Injil itu bukan perkara 
Paulus melainkan perkara dari Allah yang telah mengutus Paulus menjadi duta-Nya (Th. Van den End, 1995 : 20-21). Istilah Injil Allah mengandung arti bahwa Injil adalah berita dari Allah, yang telah menyatakan rahmat-Nya didalam kedatangan Kristus. Sebagai penyelamat seluruh ciptaan-Nya. Perkataan Yesus itu diakui oleh orang Kristen sebagai Sabda atau Firman Allah. Karena seorang pun tidak pernah melihat Allah melainkan Yesus Kristus yang memperkenalkan Allah kepada dunia ini (Yohanes 1:14-18). Jika evangelion dari bahasa dan budaya Yunani diartikan sebagai kabar baik, namun tidak semua kabar baik adalah mengandung keselamatan. Karena keselamatan bermuatan kasih Illahi yakni kasih agape artinya bahwa Allah mengasihi manusia bukan karena kebaikan manusia, melainkan semata-mata belas kasihan-Nya (Yohanes 3:16). Kasih Allah itu bersifat universal kepada seluruh dunia dan manusia, oleh sebab itu karya Allah dalam kasih-Nya yang agape itu disebut sebagai eveangelion, yaitu kabar gembira bagi umat manusia berdosa.

Kabar baik itu semakin diketahui yakni: jikalau Allah pada zaman dahulu telah berfirman melalui para Nabi kini Allah berfirman melalui perantaraan Yesus Kristus (Ibrani 1:1-4). Firman itu telah menjadi berita sukacita yaitu ketika Yesus Kristus menjelma menjadi manusia maka segenap karya Yesus Kristus seperti kelahiran-Nya, kematian-Nya, kebangkitan-Nya dan kenaikan-Nya ke surga menjadi esensi berita Injil. Melalui perjalanan waktu, dan para Rasul serta pengikut-pengikut Yesus adalah sebagai saksi mata telah meninggal dunia, maka dirasa perlu perkataan dan perbuatan Kristus dibukukan untuk menjadi dokumen tertulis. Tulisan-tulisan itu meskipun terkadang memakai nama samaran (pseudegrapha), namun satu hal yang perlu diakui bahwa para redaktur telah menulis dengan jujur, artinya melaporkan apa adanya yang telah mereka lihat dengan gaya bahasa dan metode mereka masingmasing. Tujuan mereka agar semua orang percaya bahwa apa yang telah dinubuatkan dalam Perjanjian Lama oleh para nabi adalah telah digenapi dalam diri Yesus Kristus, terutama janji Allah mengenai berita sukacita yakni penebusan dosa dan keselamatan yang dilakukan Allah dalam Yesus Kristus.

\section{BAGAIMANA TEOLOGI MEMANDANG LINGKUNGAN HIDUP}

Teologi mengungkapkan bahwa manusia diciptakan bersama dengan seluruh alam semesta. Itu berarti bahwa manusia mempunyai keterkaitan dan kesatuan dengan lingkungan hidupnya. "Namun hanya manusia yang diciptakan menurut gambar Allah (Imago Dei) yang diberikan kewenangan untuk menguasai dan menaklukkan bumi dengan segala isinya (Barth C., 1985 : 51). Maka dari satu aspek, manusia adalah bagian integral dari ciptaan atau lingkungan, akan tetapi di lain segi ia diberikan kekuasaan untuk memerintah dan memelihara bumi. Maka hubungan manusia dengan lingkungan hidupnya adalah dua sisi dari mata uang yang harus dilakukan dengan adil dan seimbang. Sebab itu secara Teologi, lingkungan hidup dapat dipahami sebagai berikut:

\section{Manusia Menyatu Dengan Lingkungan Hidup}

Para penulis Alkitab menceritakan kesatuan manusia dengan alam dalam cerita penciptaan: Tuhan Allah membentuk manusia itu dari debu tanah (Kejadian 2:7), seperti Ia juga 
membentuk dari tanah segala binatang hutan dan segala burung di udara (Kejadian 2:19). Dalam bahasa Ibrani, manusia disebut "Adam", nama itu mempunyai akar yang sama dengan kata untuk, "adamah", yang berarti warna merah kecokelatan yang mengungkapkan warna kulit manusia dan warna tanah. Dalam bahasa Latin manusia disebut "homo", yang juga mempunyai makna yang berkaitan dengan "humus", yaitu tanah. Sebab itu, tanah biasa diartikan bumi. Hubungan manusia dengan tanah dapat bermakna tiga yaitu manusia diciptakan dari tanah (Kejadian 2:7; 3:19, 23), manusia harus hidup dari menggarap tanah (Kejadian 3:23), dan manusia pasti akan kembali kepada tanah (Kejadian 3:19; Mazmur 90:3).

Disini nyata bahwa manusia dan alam lingkungan hidup, saling bergantung sesuai dengan hukum ekosistem. Karena itu, kalau manusia merusak lingkungan hidup, hal itu dapat berarti ia juga merusak dirinya sendiri.

\section{Kepemimpinan Manusia atas Lingkungan Hidup}

Kendatipun manusia dengan alam saling bergantung, namun dengan jelas adanya perbedaan manusia dengan unsurunsur alam yang lain. Hanya manusia yang diciptakan segambar dengan Allah dan diberikan kuasa untuk menguasai dan menaklukkan bumi dengan seluruh ciptaan yang lain (Kejadian 2:26-28), demikian untuk mengelola dan memelihara lingkungan hidupnya (Kej.2:15). Maka dengan demikian manusia mempunyai kuasa yang lebih besar daripada makhluk yang lain. Manusia dinobatkan menjadi "raja" di bumi yang dimahkotai kemuliaan dan hormat (Mazmur 8:6). Ia menjadi wakil Allah yang memerintah atas nama
Allah terhadap makhluk-makhluk yang lain. Ia hidup di dunia sebagai duta Allah, ia ditunjuk menjadi mitra Allah. "Karena ia menjadi wakil dan mitra Allah, maka kekuasaan manusia adalah kekuasaan perwakilan perwalian" (KarelSosipater, 2011 : 62). Kekuasaan itu adalah kekuasaan yang terbatas dan yang harus dipertanggungjawabkan kepada pemberi kuasa, yaitu Allah. Itu sebabnya manusia tidak boleh sewenang-wenang terhadap alam. Ia tidak boleh menjadi raja lalim. Kekuasaan manusia adalah kekuasaan care-taker. Maka sebaiknya manusia berlaku secara adil, seimbang perannya, artinya pengelolaan dan pemanfaatan sumber-sumber daya alam diimbangi pula dengan usaha pemeliharaan atau pelestarian lingkungan hidupnya, sehingga alam bukan sebagai objek komoditi. Kata mengelola dalam Kejadian 2:15, digunakan istilah Ibrani "abudah" yang sama maknanya dengan kata ibadah yaitu mengabdi. Maka manusia sebagai citra Allah seharusnya memanfaatkan lingkungan sebagai bagian dari ibadah dan dalam pengabdiannya kepada Allah. Penguasaan terhadap lingkungan hidup seharusnya dilaksanakan secara bertanggungjawab, yakni memanfaatkan sembari menjaga dan memelihara. Ibadah yang sejati adalah melakukan apa saja yang dikehendaki oleh Allah dalam hidup manusia, termasuk hal mengelola dan memelihara lingkungan hidup yang dipercayakan kepada manusia oleh Tuhan.

\section{Kegagalan Manusia Memelihara Lingkungan Hidup}

Dari aspek teologis diketahui bahwa "keinginan" dari manusia untuk menjadi sama seperti Allah, dan karena keinginan itu ia "melanggar" amanat Allah (Kejadian 3:5-6). Tindakan melanggar amanat Allah membawa dampak bukan 
hanya rusaknya hubungan manusia dengan Allah, tetapi juga dengan sesamanya dan dengan lingkungannya. Manusia menghadapi alam tidak lagi dalam konteks sesama ciptaan, tetapi mengarah pada hubungan tuan dengan miliknya. Manusia memperlakukan alam sebagai objek yang semata-mata berguna untuk kepentingannya. Lingkungan hidup diperhatikan hanya dalam konteks kegunaaan (utilistik-materialistik). Manusia hanya memperhatikan tugas menguasai, tetapi lupa memperhatikan tugas memlihara. Dengan demikian, manusia gagal dalam melaksanakan tugas kepemimpinannya terhadap lingkungan hidupnya. Akar perlakuan buruk manusia terhadap alam terungkap dalam istilah seperti: "tanah yang terkutuk", "susah payah kerja", dan "semak duri dan rumput duri yang akan dihasilkan bumi" (Kejadian 3:17-19). Manusia selalu dibayangi oleh rasa kuatir akan hari esok yang mendorongnya cenderung rakus dan materialistik(Matius 6:19-25). Dari aspek teologis, dapat dikatakan bahwa akar kerusakan lingkungan alam dewasa ini terletak pada sikap rakus manusia. John Stott (1994) mengungkapkan bahwa: "economic gain by environmental loss" (John Stott, 1994 : 146). Manusia berdosa menghadapi alam tidak lagi sekadar untuk memenuhi kebutuhannya, tetapi juga sekaligus untuk memenuhi keserakahannya. Dengan kata lain, manusia berdosa adalah manusia yang hakikatnya berubah dari "a needy being" menjadi "a greedy being”. Kegagalan dalam melaksanakan tugas kepemimpinan atas alam adalah kegagalan manusia dalam mengendalikan dirinya, khususnya keinginan-keinginannya.

\section{Hubungan yang Baru Antara Manusia dengan Lingkungan Hidup}

Dalam Perjanjian Baru, menceritakan bahwa Allah yang maha kasih mengasihi dunia ciptaan-Nya (kosmos), sehingga Ia mengutus AnakNya yang tunggal kedalam dunia, yaitu Tuhan Yesus Kristus (Yohanes 3:16). Tuhan Yesus Kristus yang disebut Firman (Logos) Pencipta (Kolose 1:15-17; Yoh. 1:3,10a) telah berinkarnasi mengambil bentuk materi dengan menjelma menjadi manusia (Yohanes 1:1,14) dan melalui pengorbanan-Nya di atas kayu salib serta kebangkitan-Nya dari antara orang mati, Ia telah mendamaikan Allah dengan dunia (kosmos) ini (Kolose 1:19-20; 2 Kor.5:18-19). Tuhan Yesus telah memulihkan hubungan Allah dengan manusia dan dengan seluruh ciptaan-Nya dan memulihkan hubungan manusia dengan lingkungan hidup. Atas dasar itu, maka hubungan harnonis dalam Eden (Firdaus) telah dipulihkan. Apa yang dibayangkan dalam Perjanjian Lama sebagai nubuat tentang kedamaian seluruh bumi dan diantara seluruh makhluk (Yesaya 1:6-9; 65:17; 66:22; Hosea 2:18-23) telah dipenuhi dalam diri Tuhan Yesus Kristus. Maka dalam teologi Kristen, hubungan baru manusia dengan alam bukan saja hubungan 'dominio' atau menguasai tetapi juga hubungan 'comunio' atau persekutuan. Itu sebabnya Tuhan Yesus yang telah berinkarnasi itu menggunakan pula unsur-unsur alam dalam pelayananNya, yaitu: "air, anggur dan roti" dalam sakramen yang menjadi tanda dan materai hubungan baru manusia dengan Allah. Dengan kata lain, hubungan manusia dengan Allah yang baik harus tercermin dalam hubungan yang baik antara manusia dengan 
alam. Persekutuan dengan Allah harus tercermin dalam persekutuan dengan alam. Hubungan yang baik dengan alam, sekaligus mengarahkan pada penyempurnaan ciptaan dalam 'langit dan bumi yang baru' (Wahyu 21:1-5) yang menjadi tujuan akhir dari karya penebusan Allah dalamYesus Kristus.

\section{Manusia Solider dengan Lingkungan Hidup}

Karena manusia dengan lingkungan hidup adalah sesama ciptaan yang telah dipulihkan hubungannya oleh Tuhan Yesus Kristus, maka manusia khususnya manusia baru yang diperbaharui dalam Kristus (2 Korintus 5:17) seharusnya membangun hubungan solider dengan lingkungannya. Hubungan solider sesama ciptaan dan sesama tebusan berarti lingkungan hidup seharusnya diperlakukan dengan penuh belas kasihan. Sebab itu penulis Injil Markus melihat bahwa segala makhluk menjadi alamat pemberitaan Injil. Artinya kerusakan alam oleh karena ulah manusia harus segera diselamatkan oleh orang yang percaya kepada Yesus Kristus. Manusia harus merasakan penderitaan alam sebagai penderitaannya dan kerusakan alam sebagai kerusakannya juga. Seluruh makhluk dan lingkungan sekitar tidak diperlakukan semena-mena, tidak dirusak, tidak dicemari dan semua isinya tidak dibiarkan musnah atau punah. Manusia tidak boleh bersikap kejam terhadap alam khususnya terhadap sesama makhluk. Dengan cara itu manusia dan alam secara bersama menjaga dan memelihara ekosistem. Manusia berdisiplin dalam membuang sampah atau limbah individu, rumah tangga, industri, kantor, dan sebagainya agar tidak mencemari lingkungan dan merusak ekosistem.

Pencemaran polusi mestinya dicegah, diminimalisir, bahkan dilenyapkan supaya alam tidak sakit atau rusak. Orang percaya bertanggungjawab atas kesehatan dan kesegaran alam. Sikap solider dengan alam dapat pula ditunjukkan dengan sikap hormat dan menghargai alam. Tidak berarti alam disembah, tetapi alam dihargai sebagai ciptaan yang dikaruniakan Tuhan untuk memenuhi kebutuhan manusia, sekaligus menjadi cerminan kemuliaan Allah. Menghargai alam berarti menghargai Sang Pencipta dan Sang Penebus. Tidak membabat hutan sembarangan sebab membabat hutan dapat memusnahkan aneka ragam spesies dalam hutan. Contoh lain, tidak menangkap ikan dengan menggunakan bahan peledak atau bahan pemusnah (geosida-geosida) lainnya. Sebaliknya usaha menghargai dapat dilakukan melalui usaha-usaha kreatif mendukung dan melindungi kehidupan seluruh makhluk dan lingkungan hidup misalnya dengan tidak hanya penghijauan, pembudidayaan, tetapi juga usaha pemulihan dengan membersihkan lingkungan yang terlanjur rusak. Pada intinya adalah, sikap solidaritas dengan alam dapat ditunjukkan dengan pola hidup berdisiplin dalam menjaga dan memelihara keseimbangan ekosistem secara konstan.

\section{Manusia Mewartakan Injil Kepada Lingkungan Hidup Secara Bertanggungjawab}

Alam adalah titipan dari Allah, untuk dimanfaatkan, dipakai, 
digunakan manusia memenuhi kebutuhan hidupnya, tetapi sekaligus adalah rumahnya. Maka sumbersumber alam diberikan kepada manusia tidak untuk diboroskan. Manusia harus menggunakan dan memanfaatkan sumber-sumber alam itu secara bertanggungjawab. Maka pemanfaatan/penggunaan sumbersumber alam haruslah dilihat sebagai bagian dari pelayanan. Alam digunakan dengan memperhatikan keseimbangan antara kebutuhan manusia dengan kebutuhan lingkungan, yaitu menjaga ekosistem. Alam harus digunakan dengan memperhatikan kebutuhan sesama, termasuk generasi yang akan datang. Memanfaatkan alam adalah bagian dari pertanggungjawaban talenta yang diberikan dan dipercayakan oleh Tuhan kepada manusia (Matius 25:1430). Allah telah mempercayakan alam ini untuk dimanfaatkan dan dipakai untuk dilipatgandakan hasilnya, untuk disuburkan, dan dijaga agar tetap sehat sehingga produknya tetap optimal. Oleh karena itu alam mesti dirawat dan keuntungan yang didapat dari alam sebagian dikembalikan sebagai deposit guna memelihara alam serta harus dipergunakan secara adil dengan semua orang. Ketidak-adilan dalam memanfaatkan sumber-sumber alam adalah juga salah satu penyebab rusaknya alam. Sebab mereka yang merasa kurang akan mengambil kebutuhannya dari alam dengan cara yang sering kurang memerhatikan kelestarian alam, misalnya dengan membakar hutan, mengebom bunga karang dan ikan, dan sebagainya. Sebaliknya, mereka yang tergoda akan kekayaan melakukan pengurasan sumber alam secara serakah dan tanpa batas.

Panggilan untuk memanfaatkan sumber-sumber alam sebagai pelayanan dan pertanggungjawaban talenta akan mendorong melestarikan sumber-sumber alam, sekaligus melakukan keadilan terhadap sesama. Manusia menghemat menggunakan sumber-sumber alam seperti bahan bakar fosil, hutan, mineral dan sebagainya agar tetap mencukupi kebutuhan manusia dan makhluk hidup lain secara berkesinambungan. Penghematan ini tidak hanya berarti penggunaan seminimal mungkin sumber-sumber alam sesuai kebutuhan seperti air, energi, kayu, dan sebagainya, tetapi mencakup pula pola 4R: 'reduce', 'reuse', 'recycle', 'replace' (mengurangi, menggunakan ulang, mendaur ulang, dan mengganti)sumber-sumber alam yang dipergunakan setiap hari. Dunia modern yang sangat praktis mengajar manusia memakai sesuatu barang lalu membuang. Sayangnya, yang sering dibuang itu adalah yang semestinya masih berguna didaur ulang. Tidak jarang pula yang dibuang itu sekaligus merusak lingkungan, misalnya bahan kimia atau kemasan kaleng dan plastik. Karena itu bahan-bahan yang merusak alam sebaiknya tidak digunakan terlalu banyak dan tidak dibuang sembarangan.

\section{Manusia Harus Insyaf dan Mengendalikan Diri}

Kerusakan lingkungan berakar dalam keserakahan dan kerakusan manusia. Itu sebabnya manusia yang dikuasai dosa keserakahan dan kerakusan itu cenderung sangat konsumtif. Secara teologis, dapat 
dikatakan bahwa dosa telah menyebabkan krisis moral/krisis etika, dan krisis moral ini menyebabkan krisis ekologis, krisis lingkungan. Dengan demikian, setiap perilaku yang merusak lingkungan adalah pencerminan krisis moral yang berarti tindakan dosa. Dalam arti itu, maka upaya pelestarian lingkungan hidup harus dilihat sebagai tindakan pertobatan dan pengendalian diri.

Dilihat dari sudut pandang Kristen, maka tugas pelestarian lingkungan hidup yang pertama dan utama adalah mempraktikkan pola hidup baru, hidup yang penuh pertobatan.

Morris menuliskan: "Pertobatan berarti kita mengakui bahwa kita telah gagal menjalani cara hidup yang paling tinggi dan paling baik yang kitaketahui" (Leon Morris, 1990 : 130)

Kristus mengingatkan bahaya mammonisme yang dapat disamakan dengan sikap rakus terhadap sumbersumber alam (Matius 6:19-24; 1 Timotous 6:6-10). Karena mencintai materi, alam di eksploitasi guna mendapatkan keuntungan material. Maka supaya alam tetap terpelihara dan dijaga kelestariannya, manusia harus berubah (bertobat) dan mengendalikan dirinya. Manusia harus menyembah Allah dan bukan materi. Dalam arti itulah maka usaha pelestarian alam harus dilihat sebagai ibadah kepada Allah melawan penyembahan alam, khususnya penyembahan modern alias materialisme/mammonisme.

Pelestarian alam juga harus dilihat sebagai wujud kecintaan kita kepada sesama sesuai ajaran Yesus Kristus, dimana salah satu penjabarannya adalah terhadap seluruh ciptaan Allah sebagai sesama ciptaan. Alam atau lingkungan hidup telah dikaruniakan oleh Tuhan untuk digunakan dan dimanfaatkan demi kesejahteraan manusia. Manusia dapat menggunakan alam untuk menopang hidupnya. Dengan kata lain, alam diciptakan oleh Tuhan dengan fungsi ekonomis, yaitu untuk memenuhi kebutuhan hidup manusia. Tetapi bukan hanya kebutuhan manusia menjadi alasan penciptaan, alam ini dibutuhkan pula oleh makhluk hidup lainnya bahkan oleh seluruh sistem kehidupan atau ekosistem. Alam ini berfungsi ekumenis untuk didiami oleh seluruh ciptaan lainnya. Alam ini rumah bagi manusia. Kata kata ekonomi, ekumene, dan ekologi berakar dalam kata Yunani 'oikos' yang artinya rumah. Ekonomi berarti menata rumah itulah tugas pengelolaan kebutuhan hidup. Ekumene berarti mendiami rumah: itulah tugas penataan kehidupan yang harmonis. Ekologi berarti mengetahui/menyelidiki rumah: itulah tugas memahami tanggungjawab terhadap alam.

Manusia adalah penata dalam rumah bersama ini. Ia adalah pengelola ekonomi, tetapi ia sering dikuasai oleh kerakusan. Karena itu diperlukan pembaruan/pertobatan dan pengendalian diri supaya timbul sikap respek dan tindakan penuh tanggungjawab terhadap lingkungan. Maka tanggungjawab Kristen dalam memelihara kelestarian lingkungan dapat dirumuskan dalam konsep yakni: repent, restraint, respect, resposible atau bertobat, menahan diri, menghormati dan bertanggungjawab. Ibadah yang sejati adalah ibadah yang dapat diimplementasikan secara bertanggungjawab dalam hidup yang 
nyata. Dalam menata kehidupan bersama, umat Kristen bermitra dengan semua orang bahkan dengan semua makhluk. 'Ekumene' berarti bekerja bersama membangun kehidupan diatas planet ini. Tugas itu adalah tugas bersama semua orang dan seluruh ciptaan. Maka tugas orang Kristen adalah memberi kontribusinya sesuai dengan iman dan pengaharapan kepada Allah, memperkaya dan mengoptimalkan ibadahnya dengan terus menerus menjaga dan memelihara kehidupan yang diberikan Tuhan kepadanya sebagai ungkapan syukur kepada Tuhan. Optimalisasi ibadah itu dinyatakan dalam bentuk disiplin, penghematan dan pengendalian diri.Dalam hal ini, perlu belajar dari pernyataan E.F. Schumacher, yang dikutipoleh John Stott (1994:147), berbunyi: "Small is beautiful".

\section{PENDIDIKAN BERWAWASAN LINGKUNGAN}

Masalah lingkungan adalah masalah kolektif, sehingga hanya dapat ditanggunglangi secara bersama-sama, kendatipun faktor penyebabnya mungkin oleh sekelompok kecil masyarakat bahkan oleh perorangan atau individu tertentu yang sadar atau tidak sadar melakukan pengrusakan terhadap lingkungan.

Sebaiknya masyarakat yang memanfaatkan lingkungan, baik sebagai sumber pemenuhan kebutuhan hidup sehari-hari seperti pangan, maupun sebagai tempat tinggal atau pemukiman, rekreasi, olah raga, dan tempat memproduksi barang kebutuhan hidup manusia seperti sandang dan peralatan rumah tangga atau yang lainnya, sangat penting mendapat edukasi.

Kerusakan lingkungan semakin hari semakin intensif dan terus meningkat sehingga dampaknya pada kehidupan manusia semakin berat dan kompleks. Dampak pengrusakan lingkungan oleh manusia berlangsung secara perlahan-lahan sehingga sering tidak disadari oleh pelaku pengrusakan lingkungan, karena pada awalnya lingkungan mempunyai daya toleransi dan apabila telah terlampaui batas maka kualitas lingkungan terus merosot dan berdampak pada malapetaka yang menghancurkan kehidupan manusia.

Pada awalnya manusia hanya memanfaatkan lahan untuk bercocok tanam dengan hasil awal yang sangat menjanjikan, tetapi lambat-laun kesuburan tanah semakin menurun, lapisan tanah semakin tipis, biaya pengolahan semakin mahal, dan produksi semakin merosot, akibatnya kebutuhan hidup tidak terpenuhi dan kemiskinan akan muncul. Pada saat itulah bahwa lingkungan sudah tidak mampu mendukung kehidupan serta malapetaka dan bencana alam mulai bermunculan seperti longsor, kekeringan, banjir dan kelaparan.

Masalah lingkungan terjadi secara bertahap dan perlahan-lahan sehingga hampir tidak disadari oleh pelaku pengrusakan. Begitu pula untuk memperbaiki dan menanggulanginya pun dilakukan secara bertahap dan berangsurangsur serta diperlukan waktu yang cukup lama. Karena sekali polutan masuk ke lingkungan maka diperlukan waktu ratusan tahun untuk pemulihannya. Oleh karena itu semboyan lama dalam memperbaiki lingkungan masih relevan untuk dipedomani yakni mencegah lebih baik daripada memperbaiki.

Mencegah kerusakan dan memperbaiki lingkungan perlu pemahaman yang cukup luas berkenaan dengan sistem yang terjadi di lingkungan, sehingga diperlukan program yang terencana dan jelas serta dilakukan secara bertahap dan 
sistematis. Karena dalam memperbaiki lingkungan tidak cukup dengan pengetahuan saja, tetapi harus didukung dengan mental dan perilaku serta sikap yang sungguh-sungguh dari setiap komponen masyarakat.

Untuk membentuk pola pikir masyarakat sangat perlu edukasi. Pendidikan yang berwawasan lingkungan mulai sejak pendidikan dasar sampai pada perguruan tinggi.Lingkungan hidup sebagai suatu masalah besar apabila telah merugikan dan memengaruhi kelangsungan hidup manusia. Pada awalnya, mungkin apa yang dilakukan oleh manusia pada masa lalu lebih buruk ketimbang dari masa kini. Tetapi yang membedakan pada masa lalu jumlah manusia masih sedikit sehingga kerusakan yang ditimbulkan oleh manusia masih dalam batas toleransi alam. Tetapi pada saat ini populasi manusia semakin banyak sehingga akumulasi kesalahan dalam mengelola lingkungan sudah tidak dapat ditoleransi lagi oleh alam dan pengembaliannya diperlukan waktu yang cukup lama. Oleh sebab itu edukasi untuk mengendalikan jumlah penduduk sangat berkontribusi terhadap kesehatan lingkungan hidup

Di bawah ini berbagai kegiatan manusia terhadap lingkungan yang perlu mendapatkan perhatian untuk diedukasi, antara lain:

\section{1) Sektor Pertanian}

Pembangunan bidang pertanian yang telah dilakukan ternyata telah menuai kegagalan dari sisi lingkungan, karena pada awalnya pertanian sebagai sumber kehidupan sebagian besar masyarakat Indonesia, kemudian ditata seiring dengan meningkatnya jumlah penduduk. Namun mengalami kegagalan karena muncul berbagai jenis penyakit dan hama baru yang memiliki kekebalan pada berbagai jenis racun tanaman.

Demikian juga biota air tawar musnah akibat pestisida yang digunakan sehingga kualitas generasi muda petani menurun akibat pasokan protein ikan yang biasa dikonsumsi masyarakat petani berkurang. Muncul berbagai penyakit baru di masyarakat petani karena banyak mengkonsumsi pangan yang telah tercemari oleh pestisida dan pupuk pemicu pertumbuhan tanaman. Kualitas air permukaan dan dan air tanah terus menurun karena banyak tercemari oleh pestisida dan pupuk, sehingga petani harus mengeluarkan cost tambahan untuk penyediaan air bersih. Kualitas perairan laut juga terus menurun karena muara sungai banyak tercemari air yang berasal dari daerah pertanian.

\section{2) Sektor Kehutanan}

Sektor kehutanan pada awalnya merupakan sektor yang paling diandalkan dalam pembangunan, sehingga pengeksploitasian sumber daya hutan terus menerus dilakukan tanpa mempertimbangkan aspek daya dukungnya. Manusia lupa bahwa untuk membentuk hutan yang dapat dimanfaatkan kayunya diperlukan waktu ratusan tahun, sementara waktu menghabisinya hanya beberapa saat saja. Dengan demikian, pemulihan hutan hampir tidak mungkin terjadi. Dampaknya kerusakan hutan dimanamana dan bencananya telah merusak penduduk dan masyarakat yang ada di sekitarnya. Peran edukasi dititikberatkan supaya manusia bukan hanya pintar menebang dan mamanfaatkan hasil-hasil hutan, sebaliknya harus lebih arif dan bijaksana untuk menanam kembali dan 
merawat secara baik dan bertanggungjawab.

3) Sektor Industri dan Transportasi

\begin{abstract}
Industri dan transportasi merupakan kebutuhan yang bergandengan untuk mendukung kehidupan manusia karena banyak manfaat yang dapat dihasilkan baik secara langsung maupun tidak langsung. Tetapi sampai saat ini efisiensi pemanfaatan bahan baku untuk industri dan pemakaian BBM untuk proses industri dan transportasi masih belum seimbang. Sehingga polusi dan pengurasan sumber daya alam terus berlangsung, akibatnya kualitas udara, air dan tanah terus menurun yang pada gilirannya kualitas hidup manusia juga menurun akibat berbagai penyakit yang variatif dan mematikan. Peran pendidikan sejak dini perlu memberi pencerahan kepada pengelola industri dan transportasi supaya tercipta pemahaman yang seimbang dari dampak kegiatan industri dan transportasi.
\end{abstract}

\section{4) Sektor Kualitas dan Degradasi Lahan}

Kualitas lahan yang tadinya cukup menjanjikan, akan tetapi kini terus merosot akibat adanya kesalahan dalam mengelola dan pencemaran industri dan transportasi. Daerah daratan yang tadinya identik dengan daerah persawahan sekarang banyak yang beralih fungsi menjadi kawasan industri dan permukiman. Pada lahan sawah yang masih bertahan harus memikul akibatnya dengan pengairan yang sudah tercemar dengan limbah industri sehingga selain produksinya merosot juga hasilnya telah tercemar yang jika hasil-hasilnya dijual harganya jatuh dan tidak layak untuk dikonsumsi.

\begin{abstract}
Degradasi fisik lahan terjadi sangat intensif sehingga banjir, pelumpuran dan sedimentasi di bagian hilir terus terjadi. Dampaknya air permukaan tidak dapat dimanfaatkan, air tanah semakin sedikit, areal pertanian rusak oleh genangan lumpur, produktivitas terus menurun. Dampaknya beban pemerintah dan masyarakat semakin tinggi karena bantuan pangan dan kemanusiaan untuk daerah hilir harus mengalir dan bantuan penghijauan reboisasi di bagian hulu harus dilakukan.
\end{abstract}

\section{5) Sektor Pembangunan yang Sustainable}

Lingkungan hidup yang berkelanjutan adalah lingkungan yang dapat memenuhi kebutuhan generasi sekarang dan yang akan datang. Pembangunan yang berkelanjutan (Sustainable Development) diprediksi dapat menjamin terpenuhinya kebutuhan manusia saat ini tanpa mengurangi potensi pemenuhan kebutuhan pada masa mendatang.

Sangat penting Pemerintah memberikan edukasi kepada generasi muda tentang lingkungan baik melalui pendidikan formal maupun non formal. Pendidikan sekolah misalnya, dengan menyisipkan pada mata pelajaran geografi atau mata pelajaran lain yang berhubungan termasuk pendidikan agama. Sedangkan pada pendidikan non-formal dapat dilakukan melalui kampanye sadar lingkungan dan pelatihan-pelatihan.

Lingkungan sebagai tempat hidup manusia secara alamlah kualitasnya terus merosot seiring dengan semakin meningkatnya jumlah penduduk. Tetapi yang menjadi tanggungjawab manusia saat ini adalah bagaimana caranya agar kerusakan tersebut tidak 
terlalu cepat sehingga lingkungan memiliki kesempatan untuk pulih kembali dan lingkungan dapat mendukung kehidupan secara berkelanjutan.

Jika dicermati, umumnya penduduk Indonesia berlatarbelakang pendidikan Sekolah Dasar, hal ini menunjukkan bahwa tingkat pendidikannya masih sangat rendah, maka wajar jika pemahaman pada lingkungan masih terbatas. Tetapi kenyataannya, kesalahan yang dilakukan oleh manusia berpendidikan rendah tidak seberat yang dilakukan oleh manusia yang berpendidikan tinggi. Sehingga perlu dirumuskan bentuk dan informasi yang harus disampaikan agar kerusakan lingkungan dapat dihambat.

Masalah lingkungan sering diabaikan dan tidak diperhatikan oleh sebagian orang, karena sangat sulit jika dikalkulasi untung ruginya secara individu atau keluarga dan dampaknya kurang dapat dirasakan secara nyata. Sebagai contoh, kesadaran masyarakat untuk membuat septictank lebih responsif karena jika tidak dibuat, akan bau dan menimbulkan penyakit. Tetapi jika disuruh membuat sumur resapan, masyarakat sangat sulit untuk melaksanakannya karena setelah membuat sumur resapan masalah banjir dan kekeringan akan terjadi karena manusia yang lain tidak ikut melakukannya.

Dibawah ini diketengahkan contoh yang kurang peduli pada pendidikan lingkungan yang sustainable antara lain:

a. Pada Tingkat PAUD dan Taman Kanak-kanak

Sering memperkenalkan buah-buahan dan sayuran, seperti pada permainan bongkar pasang dan menggambar yang disajikan adalah produk pertanian di daerah iklim sedang. Sehingga anak-anak lebih menyukai tanaman iklim sedang daripada tanaman tropika. Sementara anak-anak Indonesia berada di daerah tropis.

b. Pada Tingkat Pendidikan Dasar

Sering disajikan informasi bahwa Indonesia tanahnya subur dan kaya raya, bahkan tongkat kayu dilempar pun jadi tanaman. Padahal kondisi alam kita tidak seperti itu sehingga anak-anak menjadi menjadi malas. Seharusnya diberi edukasi bahwa zaman dulu mungkin demikian, tetapi kini sudah berubah karena kerusakan lingkungan. Maka perlu dididik anak bangsa ini supaya menyadari keadaan yang sebenarnya, sembari dimotivasi untuk bekerja keras, cerdas dan ikhlas merawat dengan baik lingkungan hidupnya masingmasing

c. Pada Tingkat Pendidikan Menengah

Pemahaman dan perilaku siswa tidak diajak pada pemahaman nyata, seperti pengetahuan tentang tindakan konservasi tidak diiringi dengan contoh di sekolah, misalnya: dibuat sumur resapan agar air yang jatuh di sekolah tidak mengalir ke luar; halaman terbuka untuk istirahat siswa hampir tidak ada karena dibuat bangunan untuk tambahan kelas baru, ruang laboratorium, ruang serbaguna, kantin dan ruang lain yang berlantai beton dan tembok, kalau 
ada tanaman pun menggunakkan pot.

\section{d. Pada Perguruan Tinggi.}

Sikap dan perilaku mahasiswa dijauhkan dari kondisi alam nyata dan bersifat konsumtif. Seperti pada saat orientasi mahasiswa kegiatannya diarahkan untuk mencari dan membeli barang dan alat-alat yang kadang-kadang tidak bermanfaat seperti balon gas dan karung terigu. Padahal akan lebih bermanfaat jika membawa bibit tanaman untuk program penghijauan dan lain-lain.

\section{PENUTUP}

Lingkungan hidup sebagai anugerah Tuhan kepada seluruh umat-Nya untuk dimanfaatkan melanjutkan hidup di tengah-tengah dunia ini, supaya mengalami damai sejahtera bahkan kemakmuran secara utuh. Sebab itu penulis Injil Markus mewartakanpemberitaanInjilkepadasegala makhluksebagaialamatkeselamatandari Allah.

Pemahaman pemberitaan Injil kepada segala makhluk dari versi Markus 16:15-16, dapat diartikan dua bagian, yaitu:

1. Memberitakan Injil kepada dunia atau kepada segala makhluk adalah sebagai perintah Tuhan Yesus setelah kebangkitan-Nya kepada seluruh pengikut-Nya yaitu murid-murid-Nya. Penulis Injil Markus memahami dunia bukan hanya dalam arti geografis, melainkan sebagai bentuk kiasan kepada orang-orang jahat yang menolak penebusan dan keselamatan dari Allah di dalam Kristus.

2. Dengan demikian hendak menyatakan bahwa Yesus Kristus memerintahkan kepada orang-orang percaya untuk mewartakan keselamatan kepada orang-orang jahat yang menentang keselamatan yang telah disediakan Allah oleh kematian dan kebangkitan Kristus. Orang berdosa identik dan sinonim dengan orang-orang dunia. Maka sangat relevan bahwa gereja memiliki 3 (tiga) tugas pokok di dunia ini, yakni koinonia, diakonia dan marturia.

Tugas panggilan marturia salah satu unsurnya adalah memberitakan Injil ke luar untuk membebaskan, melepaskan manusia pada pola pikir dan mindset yang bersifat duniawi, dimana ciri manusia berdosa diantaranya memiliki perilaku dan tindakan kejahatan mengeksploitasi sumber daya alam tanpa melakukan reduce, reuse, recycle dan replace.

3. Jika manusia telah berubah mindset dari perilaku dan tindakan kejahatan eksploitasi terhadap sumber-sumber daya alam, maka pemberitaan Injil kepada segala makhluk dan lingkungan hidup dapat dilaksanakan dengan baik. Manusia yang telah menerima Injil sebagai berita keselamatan dan kelepasan maka mereka bertanggungjawab memelihara dan melestarikan alam atau lingkungan hidupnya masing-masing.

Tuhan menciptakan lingkungan hidup mempunyai fungsi ekonomi guna manusia memenuhi kebutuhannya. Namun Tuhan menciptakan lingkungan hidup bukan hanya pemenuhan kebutuhan ekonomi tetapi juga untuk kebutuhan makhluk lain dalam rangka melanjutkan hidupnya. Karena itu fungsi lingkungan hidup adalah untuk keberlangsungan ekosistem. Oleh sebab itu lingkungan hidup atau alam ini dianggap sebagai rumah oikos, sedangkan ekonomi dalam konteks ini dapat diartikan menata rumah, dengan demikian tugas manusia sebagai Imago Dei 
adalah mengelola kehidupan, bukan saja kehidupan manusia tetapi juga kehidupan makhluk lain yang saling membutuhkan dan saling mendukung demi kelangsungan hidup bersama.

Pada tulisan ini diharapkan supaya berjalan fungsi dan tugas masing-masing makhluk, perlu ada edukasi yang terprogram kepada manusia baik secara formal maupun non-formal dalam menata kehidupan lingkungan hidup sejak dini sampai pada perguruan tinggi.

\section{DAFTAR PUSTAKA}

[1] Barth. C., 1985.Theologia Perjanjian Lama 1, Jakarta : BPK Gunung Mulia

[2] Douglas. J.D., (Penyunting/Pengelola), 1992.Ensiklopedi Alkitab Masa Kini, Jakarta : Yayasan Komunikasi Bina Kasih/OMF
[3] Herlianto,1998. Pelayanan Perkataan, Urban Ministry-Tanggungjawab Orang Kristen, YABINA

[4] Mcelrath.W.N., Billy Mathias, 1978. Ensiklopedi Alkitab Praktis, LLB, JawaTimur

[5] Morris. Leon, 1990. Teologi Perjanjian Baru, Yayasan Penerbit Gandum, Jawa Timur

[6] Sosipater. Karel Sosipater, 2011.Etika Taman Eden, Jakarta : Suara Harapan Bangsa

[7] Stott.John, 1994. Isu-isu Global Menantang Kepemimpinan Kristen, Yayasan Komunikasi Bina Kasih/OMF.

[8] Van den End.Th., 1995. Tafsiran Alkitab Surat Roma, Jakarta : BPK Gunung Mulia 